This article was downloaded by: [Australian National University Library]

On: 16 December 2010

Access details: Access Details: [subscription number 907447645]

Publisher Routledge

Informa Ltd Registered in England and Wales Registered Number: 1072954 Registered office: Mortimer House, 3741 Mortimer Street, London W1T 3JH, UK

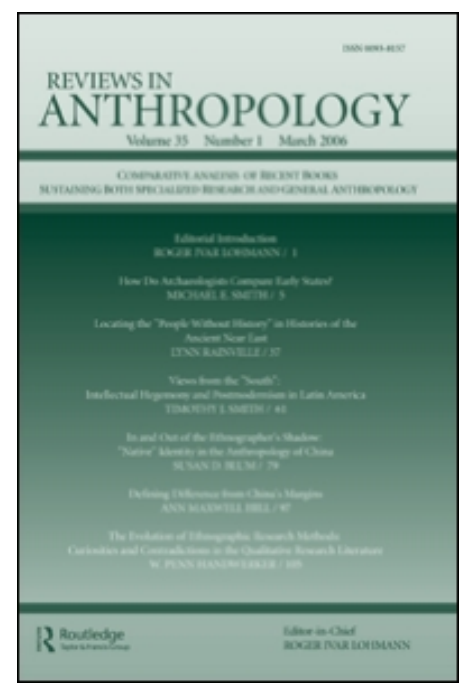

\title{
Reviews in Anthropology
}

Publication details, including instructions for authors and subscription information:

http://www.informaworld.com/smpp/title content=t713649311

\section{Synthetic Histories: Possible Futures for Papuan Pasts}

CHRIS BALLARD

Online publication date: 15 December 2010

To cite this Article BALLARD, CHRIS(2010) 'Synthetic Histories: Possible Futures for Papuan Pasts', Reviews in Anthropology, 39: 4, $232-257$

To link to this Article: DOI: $10.1080 / 00938157.2010 .524865$

URL: http://dx.doi.org/10.1080/00938157.2010.524865

\section{PLEASE SCROLL DOWN FOR ARTICLE}

Full terms and conditions of use: http://www.informaworld.com/terms-and-conditions-of-access.pdf

This article may be used for research, teaching and private study purposes. Any substantial or systematic reproduction, re-distribution, re-selling, loan or sub-licensing, systematic supply or distribution in any form to anyone is expressly forbidden.

The publisher does not give any warranty express or implied or make any representation that the contents will be complete or accurate or up to date. The accuracy of any instructions, formulae and drug doses should be independently verified with primary sources. The publisher shall not be liable for any loss, actions, claims, proceedings, demand or costs or damages whatsoever or howsoever caused arising directly or indirectly in connection with or arising out of the use of this material. 


\title{
Synthetic Histories: Possible Futures for Papuan Pasts
}

\author{
CHRIS BALLARD \\ Pawley, Andrew, Robert Attenborough, Jack Golson, and Robin Hide, eds. \\ Papuan Pasts: Cultural, Linguistic and Biological Histories of Papuan-Speaking \\ Peoples. Canberra: Pacific Linguistics, Research School of Pacific and Asian Studies, \\ The Australian National University, 2005.
}

\begin{abstract}
This article considers the case for synthetic bistories - broad narratives of bistorical process that critically combine the insights and perspectives of research from multiple disciplines. Drawing on the 28 contributions to the edited volume Papuan Pasts, on the deep bistory of the Papuan peoples, a brief synthesis of findings is offered in the form of a narrative. This enables the identification of a series of gaps, not just in the spatial and temporal coverage of research but also in the range of perspectives employed. The absence of Papuan voices is particularly challenging, and suggests that the future of Papuan histories lies in the closer articulation of a concern for deep time and questions of the genesis and immediate past of living Papuan communities.
\end{abstract}

KEYWORDS anthropological bolism, austronesian, historical synthesis, multi-disciplinary inquiry, Papuan

\section{A RECIPE FOR COMPLEXITY}

Take a large, tropical island - a very large, tropical island-positioned toward one end of the world's most extensive archipelago, itself surrounded by a further string of satellite islands. Fairly swiftly, in geological time, push the island's interior up to 5,000 meters (or high enough for glaciers to become established), and then fold it back on itself to create a series of large

Address correspondence to Chris Ballard, School of Culture, History and Language, College of Asia and the Pacific, The Australian National University, Canberra, ACT 0200, Australia. E-mail: chris.ballard@anu.edu.au 
valleys along the central spine. Allow it to set, un-colonized by major predators including humans. Then, in one movement (or more), introduce people. Set to bake for at least 40,000 years, turning up the heat and adding further ingredients from about 3,300 years before the present. Remove to global temperature, introduce missions, carve up for colonial administration, and allow for political independence. Serve to researchers (will feed a multitude indefinitely).

Large cookbooks may be back in vogue but this guide to Papuan pasts (Pawley et al. 2005), which weighs in at a mighty 817 pages with 28 chapters, still manages only to scratch at the surface of a regional history remarkable for its complexity and depth. With some 1,100 distinct languages, or one-fifth of the world's total, a correspondingly rich diversity of cultural practices, and an exceptional antiquity of continuous human occupation, New Guinea, together with the smaller surrounding islands to its west, north, and east, presents an unrivalled quality of historical complexity (Figure 1).

There is no faulting the scale of ambition on the part of the editors, who have assembled 45 contributors from linguistics, archaeology, sociocultural anthropology, environmental history, human geography, human biology, and genetics. Much of the research reported is relatively recent, reflecting new technologies, new finds, and new ideas. But Papuan Pasts is also a summation of the previous 40 years of research, providing a snapshot of the strengths and weaknesses, emphases, and blind spots of this particular regional focus. The contributions derive largely from papers presented at a conference held in Canberra in 2000, at the Australian National University or ANU, the launching pad for much of the post-war "mapping" of Melanesian societies.

Papuan Pasts contributes to a recent spate of syntheses addressing the histories of entire regions, juggling — at varying degrees of difficulty — with

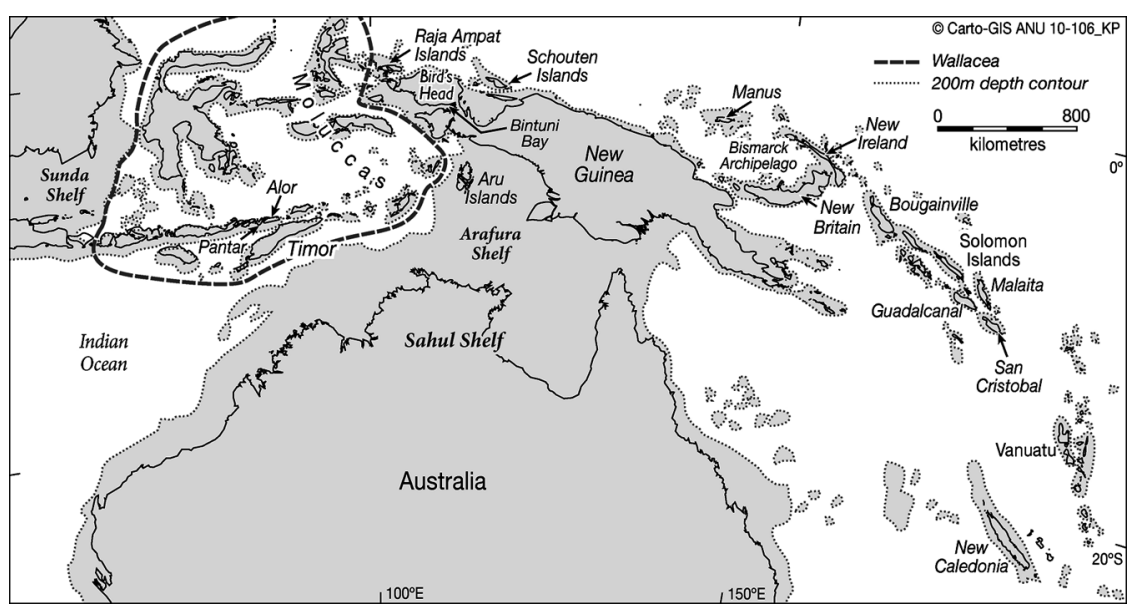

FIGURE 1 New Guinea and the paleo-continent of Sahul. 
either two (McConvell \& Evans 1997, Hill \& Santos-Granero 2002), three (Bellwood \& Renfrew 2002; Sagart et al. 2005; Friedlaender 2007a; SanchesMazas et al. 2008), or four (Bellwood et al. 1995) disciplinary or subdisciplinary perspectives (see Gruhn 2006 for a recent review of cross-disciplinary strategies generally). In part, these studies reflect the need to accommodate dramatic developments since the mid-1980s in the technology and sophistication of genetic analyses, but they also represent summary statements by a generation of researchers who have been active since the 1960s and 1970s.

Each of the four thematic sections in Papuan Pasts (on Linguistics, Archaeology, Environment, and Human Biology) opens with a useful overview by one or more of the editors, introducing individual chapters and sketching something of the specific field. Yet the overwhelming impression of the volume, taken as a whole, is of an almost bulimic disgorging of factsconfirmation, if any were needed, of the considerable complexity of the history of New Guinea and its surrounding islands. What appears to be missing from the volume - and editorial exhaustion might well account for this - is any concluding synthesis of the different disciplinary perspectives of the sort called for by general anthropology, whether in the form of a consensus narrative, or as a series of questions setting an agenda for the next decade or more of research, with clear implications for cross-disciplinary testing.

Other reviews of Papuan Pasts have listed and appraised individual contributions (see especially Bellwood 2005a, Kennedy 2006, Terrill 2007). With a more generous allowance, what I offer here instead is a synthetic account of the volume's findings, taken as a whole and with as few qualifying statements as possible, followed by some critical reflections on the future of research in this field, and the value of anthropological holism in historical inquiry. The intention of this synthesis is not to advocate for a single unitary or orthodox narrative for regional history, but rather to attempt to establish a basal level of commensurability between widely differing disciplinary perspectives. The goal of such a narrative should be to reflect fundamental convergences of opinion and analysis, while preserving differences, in recognition of the relative newness of the field of Papuan history, for which such statements are rare, and as a means of identifying areas for further inquiry.

But first a brief admission: I am very much a product myself of the ANU generally, and of its Melanesian research focus in particular. I presented a paper at the Papuan Pasts conference: a premature attempt to embed within broader social and historical contexts a series of possible cognate sets drawn from the lexicons of New Guinea highlands crop registers and agricultural practices, a project that required more competence and time than I could muster for inclusion in the present volume. Any commentary or criticism on the volume, and on the wider enterprise of which it forms a part, should thus be understood to address my own work, along with that of my colleagues. 


\section{"PAPUA" AND THE "PAPUANS"}

The Papuas... seem to be all divided into very small states or rather societies, very little connected with each other. Hence their language is broken into a multitude of dialects, which in process of time, by separation, accident, and oral corruption, have nearly lost all resemblance. [Leyden 1811:218]

Western speculation on New Guinea and the nature of its inhabitants has a long antiquity, and the toponym "Papua" and ethnonym "Papuan" come to us trailing long genealogies of confused and often contradictory usage (Gelpke 1993). Initially a cardinal direction from the perspective of the northern Moluccas, "Papua" became increasingly identified in European texts from the 16th to early 19th centuries with the island of New Guinea and the Schouten and Raja Ampat Islands, and biologized as a term for their inhabitants (Ballard 2008). The linguist Sidney Ray (1926:24) offered the definitive statement of "Papuan" as a uniquely linguistic category in 1892, contrasting Papuan languages with the Melanesian languages of the Taiwan-derived Austronesian family of languages:

For these non-Melanesian languages of New Guinea I used the name Papuan. This did not imply any community of character or origin in the language so-called, but merely served as a convenient term to indicate their archaic features as the probably aboriginal languages of the great island of New Guinea. [Ray 1926:24]

As several contributors to Papuan Pasts acknowledge, "Papuan" is a curiously residual category, gathering together all those groups that do not possess a language identified as Austronesian (Bellwood et al. 1995; Spriggs 2007); a largely obscured subcategory of the more prominent geographical and racial distinction between Melanesian and Polynesian (Thomas 1989); and in many respects a less-favored or marginal topic in the long history of the West's fascinated contemplation of all things Polynesian, Ancestral Polynesian, or Proto-Oceanic (Kirch \& Green 2001). Papuans feature overwhelmingly in this literature in terms of how much (or how little) they contribute culturally, materially, linguistically, or genetically to the origins of the Polynesians.

The linguistic frame of reference still dominates, and the scope of this volume is essentially defined as the deep history of all those communities speaking non-Austronesian languages on New Guinea or in the surrounding islands of eastern Indonesia, the Bismarck Archipelago, and Solomon Islands. The guiding assumption, following Ray, is that these communities represent descendants of the pre-Austronesian-speaking inhabitants of the region. However, one unfortunate consequence of this emphasis is an 
effective temporalization of the category, Papuan, which comes to stand not just for the non-Austronesian, but also for the pre-Austronesian.

On the first page of the preface, we are told that the book "brings together the latest research on the history of humans in Near Oceania between the first arrivals more than 40,000 years ago and the first movement into Remote Oceania" (Pawley 2005a:xi). This might be taken to imply that Papuan history ceases to be as interesting or alluring for researchers after the postulated appearance of Austronesian languages in the region at about $3300 \mathrm{BP}$, and their diffusion as Proto-Oceanic languages into the Pacific from about 3200 BP. Similarly, the use - now widespread - of the regional label "Near Oceania" for the area settled during the late Pleistocene by nonAustronesian speakers, necessarily invokes its corresponding term, "Remote Oceania," and conditions us to understand New Guinea and its archipelago as the harbinger of other movements and other histories (Pawley \& Green 1973; Green 1991). Despite the important challenge to the profoundly flawed Melanesia/Polynesia distinction, and its undoubted heuristic value as a biogeographical and chronological boundary, "Near Oceania" can be understood as a term generated essentially from the perspective of those interested primarily in accounting for the populations of "Remote Oceania."

\section{SYNTHESIS AND SPECULATION}

What, in the wake of this volume, can be said with any degree of confidence about this 40,000-year history? The synthesis that follows derives, without distinction, from all of the contributions to Papuan Pasts. It also draws on more recent work, particularly in the dynamic field of population genetics, where the rapid pace of development since the 2000 conference, in technology and in the sophistication of analysis, has transformed our understanding of the scope for historical inquiry. A synthetic account has some value, not just as a means of communicating results to a broad non-specialist readership, but also as a strategy for identifying gaps in our overview and for promoting what Allen and O'Connell (2008:31) describe as "constructive, theoretically driven, potentially testable speculation." The quality of a historical narrative is a serious barometer of the depth of evidential resources and theoretical sophistication brought to bear on specific questions, and of our capacity to assemble and critically interrogate lines of evidence drawn from multiple disciplines.

Pacific or Oceanic anthropology has a long history of collaborative or holistic inquiry involving not just multiple subfields and disciplines but also multiple national traditions. Less explicitly debated or theorized than the "sacred bundle" of four-field anthropology in North America (Segal \& Yanagisako 2005; Harkin 2010) or holistic anthropology in Europe (Parkin \& Ulijaszek 2007), Oceanic anthropology_possibly constrained or enjoined 
by the richness of regional cultural and linguistic diversity-has led the way in putting multi-disciplinary, general anthropological research into practice; perhaps the best examples being the collaborative case study in historical anthropology and archaeology of the Anahulu Valley in Hawai'i by Patrick Kirch and Marshall Sahlins (1992), and the explicitly holistic anthropological exploration of Ancestral Polynesia by Kirch and Roger Green (2001).

There is a surprising degree of consensus among the different contributions to Papuan Pasts, both within and between disciplines, and certainly by comparison with the vigor of debate surrounding Austronesian historythough this may simply reflect the limited materials available until recently for the reconstruction and interpretation of Papuan history, rather than a diminished scope for contention. Archaeological evidence for Papuan history is very limited indeed, with few strong regional sequences capable of characterizing entire economies or social systems, and vast gaps in chronologies. Andrew Pawley identifies a 20-year hiatus in focused attention on Papuan linguistics after 1975, and describes linguistic understanding of the largest of the Papuan families as being "about where Indo-European studies were in the 1820s" (Pawley 2005b:100). Biological anthropology's studies of Papuans have a long (and not always respectable) pedigree but have been revolutionized by the development of new analytic techniques, enabling a sophistication in the characterization of historical relationships that presently outstrips the precision of sampling strategies for such a diverse population. The environmental history of the region is broadly understood, but the scale of geomorphic transformation along the northern and southern coastlines of New Guinea, in particular, has only recently been appreciated. Ethnographic studies enjoy perhaps the most complete coverage of any discipline in the region, with detailed descriptions of hundreds of Papuan societies now avail-

able, but here the problem is one of articulation with historical questions - a challenge to which I return later.

\section{First Settlers}

Dates for the initial human settlement of the paleo-continent of Sahul, consisting of New Guinea, mainland Australia, Tasmania, and the Aru Islands (Figure 1), are still hotly disputed, with opinion divided between the "long chronology" of an earlier colonization between 50,000 and 60,000 years before the present or BP (O'Connor \& Chappell 2003) and the "short chronology" which would envisage first settlement from the later date of about 45,000 BP (Allen \& O'Connell 2008). Whichever the date, the ultimate origin of these first settlers must have been the paleo-continent of Sunda, the shelf extending from mainland Southeast Asia into western Indonesia, which was exposed during glacial maxima.

The precise route taken through the islands of Wallacea, the intermediate zone between the Sunda and Sahul shelves, is also a matter for 
conjecture: the earliest dates for human occupation of Wallacea derive from islands along a southern route, through Timor (O'Connor 2007), but Allen and O'Connell (2008) mount the case for a northern route through the central or northern Moluccas to the Bird's Head region of western New Guinea, and propose an early bifurcation of movement either along the northern coast of New Guinea or to Australia and southern New Guinea via the exposed Arafura shelf. They also invoke the demands of demographic viability to suggest that these initial colonists must have maintained contact for some period of time with their source communities in Wallacea, implying more than just a casual seafaring competence. This proposition finds support in the subsequent and fairly rapid colonization by sea of New Britain and New Ireland by at least 39,000 BP, and of Greater Bougainville by 32,000 BP and Manus by 24,000 BP (Specht 2005:238-239), the latter involving perhaps the first completely "blind" sea crossing in the region, between islands that were not intervisible. This Late Pleistocene colonization extended as far south as Tasmania and (presumably, for dated evidence is yet to be found) as far east as the islands of Guadalcanal, Malaita, and San Cristobal in the Solomon Islands, though populations at these extreme points are likely to have remained sparse. Archaeological and genetic evidence suggest that there was little subsequent exchange between these early populations of Bougainville and the Bismarck Archipelago after first settlement, possibly until the expansion of the Proto-Oceanic subgroup of Austronesian languages from about 3200 BP (Friedlaender 2007b:232; Summerhayes 2007:17).

At these deep time scales, the question of affinity between the inhabitants of what would become the separate landmasses of New Guinea and Australia is not easily determined. Genetic studies indicate a common origin for Australians and Papuans, but also a very early separation and surprisingly limited subsequent exchange (Hudjashov et al. 2007); linguistic evidence for affinity between the two is even harder to identify (Nichols 1997; Reesink et al. 2009). Genetic signatures become clearer once these early founder groups begin to differentiate. The specific DNA haplotypes (sets of linked genetic variants in a single DNA sequence) and haplogroups (related groups of haplotypes) can be used to identify initial or very early settlement of New Guinea, e.g., the Mitochondrial DNA haplogroups P and Q, and the Y-chromosome C-M38 and K-M9 (Kayser et al. 2003; Easteal et al. 2005:724; Friedlaender et al. 2005:712).

The exceptional temporal depth for the occupation, presumably by small founder populations, of a continent marked by extreme environmental variation allows for the operation of isolation and genetic drift as the principal determinants of linguistic, genetic, and cultural variability. In the Bismarck Archipelago and Bougainville areas, where the situation is marginally less complex, genetic variation emerges as essentially a function of island size, topographical complexity, and geographical distance from other 
islands, producing a remarkable degree of variation both within and between different islands (Friedlaender 2007a).

The subsistence base of these first colonizers appears to have reflected wide-ranging procurement strategies involving "small groups of mobile, broad-spectrum foragers" - a "world without any ethnographic parallel" (Gosden quoted in Summerhayes 2007:11). A significant line of evidence for subsistence during this early period derives from the presence by 20,000 $\mathrm{BP}$ on Bougainville, the Admiralty Islands, and the Bismarck Archipelago of one or more elements of a suite of tree crops, including Canarium indicum, and animals including two species of cuscus (Phalanger orientalis and Spilocuscus kraemeri), a bandicoot (Echymipera kalubu), and three rat species, all of which must have been transported with or by humans - the earliest evidence for such practices in the world (Summerhayes 2007; Matisoo-Smith 2007). Similarly flexible strategies are likely to have been pursued in interior New Guinea: in the highlands, where sustained exploitation from as early as 35,000 BP appears to have targeted resources such as the various edible Pandanus species and large fauna, possibly including a number of megafauna species that disappear from the record at about this time (Fairbairn et al. 2006; but see Denham 2007a for the case for a much broader spectrum of resource strategies); and in the lowlands, where Paul Roscoe's (2005: 569-575) intriguing review of contemporary sago-dependent hunter-gatherer communities suggests a series of possible models for either terrestrial or salt- and freshwater aquatic subsistence strategies and settlement patterns.

\section{Differentiation and Innovation}

Demographic viability on Sahul, combined with sea-level rise after the Last Glacial Maximum at 21,000 BP, effectively reduced the scope for further exchange in population or materials with Wallacea. The possibility of continued population movement into Sahul during the Late Pleistocene is by no means ruled out, but neither are there clear genetic or linguistic markers that would insist on further inputs. There are, however, important lines of evidence for resumed or continued exchange in both directions during the Holocene, including the human transport of the marsupial phalanger or cuscus from New Guinea to Timor before 9000 BP, and the westward spread of edible bananas from New Guinea before 5000 BP (Anderson \& O'Connor 2008:3; Kennedy 2009).

Environmental changes set significant parameters for human activity until the early or mid Holocene. The gradual rise in sea level after 21,000 BP produced contrasting effects on the steep northern coast of New Guinea, which experienced little change in overall form, and on the gently shelving southern coast, vast areas of which were inundated before being finally separated from Australia at about 8000 BP (Chappell 2005:527-528). Sea levels continued to rise until about $6000 \mathrm{BP}$, swallowing up much of the Fly-Digul 
Platform of southern New Guinea, and possibly isolating the Bosmun Plateau as an island (Figure 2). Equally dramatic was the appearance of an inland sea along the lower reaches of the Sepik and Ramu rivers, which reached its maximum extent between 6300 and $7500 \mathrm{BP}$, retreating toward the present coastline by about 4000 BP (Chappell 2005:534-536). From about 8500 BP, and following a long phase of climatic instability between 20,000 and $11,500 \mathrm{BP}$, highland climates also ameliorated significantly (Hope \& Haberle 2005:547), creating conditions that enabled the development of some of the world's earliest agricultural systems on the margins of the Wahgi Valley wetlands (Denham 2007b). The present distribution of Papuan populations bears a strong imprint of the influence of these fundamental environmental parameters.

Perhaps the most significant finding of Papuan Pasts is the convergence of evidence from each of the disciplines represented for the relationship between the development of agriculture in the central highlands and the massive expansion of the Trans New Guinea (TNG) family of languages. This would seem to offer a classic test case for current debates over the farming/ language dispersal hypothesis (Bellwood 2005b; Smith 2010). The careful review by Andrew Pawley and Malcolm Ross of earlier claims for TNG and forensic sifting of the linguistic evidence has confirmed the membership in their revised version ("TNG IV") of some 350-450 languages, which began to separate between about 10,000 and 6000 BP (Pawley 2005b:101;2007; see also Reesink et al. 2009). Further support for the apparent integrity of this family might be interpreted from a recent genetic study which proposes that the TNG expansion can be identified with the distribution of two specific Y-chromosome haplogroups, M-P34 and K-M254 (Mona et al. 2007).

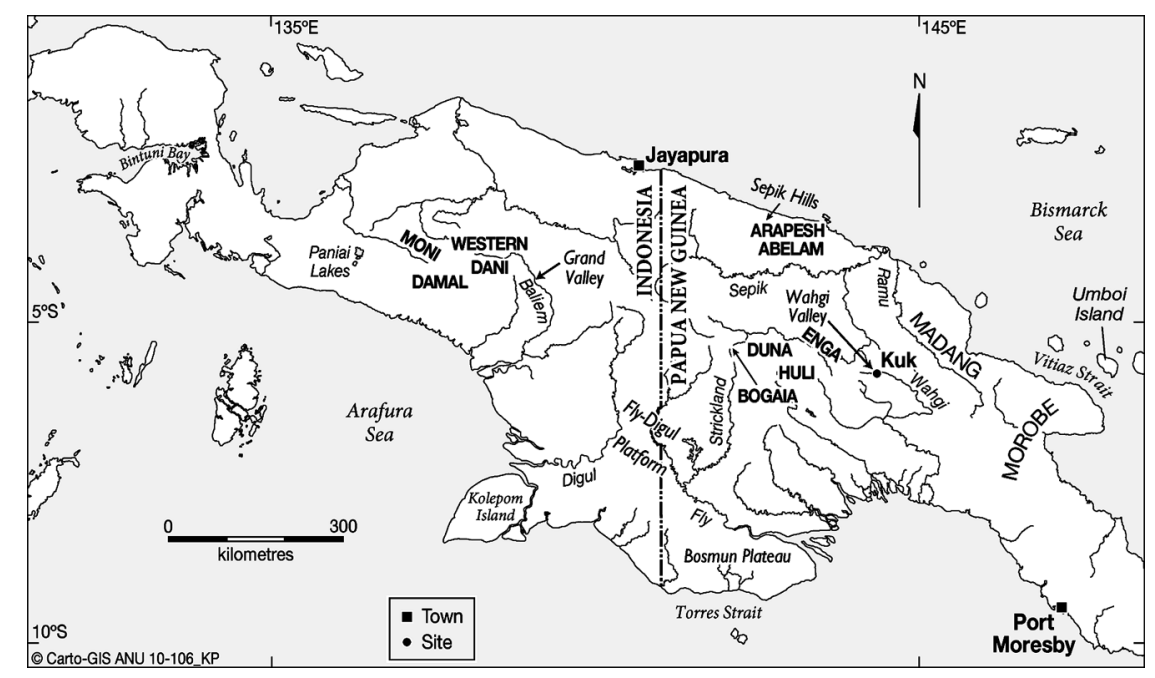

FIGURE 2 Locations, features and language communities in New Guinea. 
The likely origin of the TNG family is tentatively identified as the major valleys of the Papua New Guinea (PNG) highlands, possibly including areas of Madang and Morobe provinces to the north and east. However, the present distribution of TNG languages ranges from near the southeastern tip of PNG through the full length of the highland spine of New Guinea, and includes large swathes of southwestern New Guinea, Madang and Morobe provinces, and the Bintuni Bay area of the Bird's Head. In addition, and probably as a later movement, TNG languages have spread to the island of Umboi, in Vitiaz Strait, and to the eastern Indonesian islands of Alor, Pantar, and Timor, where Melanesian Y-chromosome lineages are common (Mona et al. 2009; Cox et al. 2010); but there are no TNG languages found in the Bismarck Archipelago.

Beyond the highlands, TNG expansion appears to have been restricted in a number of directions, including some of the more environmentally stable lowland and coastal zones, such as the Bosmun Plateau, and the entire north coast of New Guinea from near the mouth of the Ramu River as far west as the Bird's Head. Together with the scattered surviving Papuan languages of the Bismarck Archipelago and Solomon Islands, the languages of these areas are rather unfortunately characterized as "relic" (Pawley 2005a:xv) or "pre-agricultural" (Ross 2006), but in their astonishing diversity, recognized as the highest in the world, they probably do represent a level of variation that may have been universal for New Guinea prior to the homogenizing spread of the TNG family.

No single factor is likely to account for all the components and phases of the TNG expansion, but the accumulation of evidence for the local domestication of staple crops and the emergence of intensive forms of agriculture in the central highland valleys of PNG over exactly the period identified for the initial break-up of the TNG family makes for a compelling case. The long-term work of archaeologist Jack Golson and his team at the early wetland agricultural site of Kuk and elsewhere in the PNG highlands, extended and revised more recently by Tim Denham, provides the basis for the present consensus that the TNG expansion was fueled, at least initially, by intensive cultivation of locally domesticated crops, including Colocasia taro and bananas (Musa spp., section Eumusa) (Denham \& Donohue 2009; Kennedy 2009). While the process of domestication is likely to have been underway during the terminal Pleistocene, and some of the earlier phases of Kuk can less certainly be identified with drainage for intensive cultivation, there is now solid evidence for clearance of the adjacent dry lands from 10,000 BP and agricultural use of the swamp margins from between 6950-6440 BP (Denham 2007b; Denham et al. 2008). Of the various food crops putatively assigned to this period, only one can be assigned a tentative lexical reconstruction at this stage: ${ }^{*} m V$ or possibly ${ }^{*} m a$, for Colocasia taro, a reconstruction with reflexes throughout the PNG highlands (Pawley 2005b:97). For the highland areas of New Guinea at least, successful 
language families are perhaps best defined (with apologies to Max Weinreich's more martial formulation) as dialects with a tuber.

Other food crops now thought to have been domesticated or hybridized in New Guinea and Island Melanesia include other bananas (Musa spp. Section Australimusa), Cyrtosperma taro, Dioscorea alata yam, sugarcane, cordyline, galip nut (Canarium indicum), coconut, breadfruit, sago, and a range of edible pandanus species (Kennedy \& Clarke 2004; Allaby 2007). The evidence for animal domesticates in New Guinea and Island Melanesia prior to $3300 \mathrm{BP}$ is less certain. The presence of dogs in either Australia or New Guinea is not clearly attested before about $3500 \mathrm{BP}$, and previous claims for pig in New Guinea prior to 3300 BP have not been confirmed by recent direct dating of remains (Savolainen et al. 2004; Matisoo-Smith 2007).

Archaeological studies of stone artifacts are beginning to yield information suggestive of regional distinctions and discrete spheres of trade and interaction within New Guinea. The hafting of stone blades as either axes or adzes is strongly influenced by cultural preference and not simply a matter of efficiency, and the distribution of distinct hafting styles is quite discrete; Golson's suggestion (2005:474) that a particular style of adze (T1) may be linked to the initial spread of tree-clearing as an early agricultural practice is an elegant example of an archaeologically testable proposition, founded on the observation of ethnographic distributions. Similarly, the close correlation between the distribution of the enigmatic complex of stone mortars, pestles, and other carved artifacts, generally dated between 8000 and 3000 $\mathrm{BP}$, and prime agricultural land in both the highlands and lowlands of eastern New Guinea, may reflect the early expansion of TNG language communities and of their exchange networks (Swadling \& Hide 2005:293-306; Swadling et al. 2008). The dramatic decline in frequency of these artifacts to the west of the PNG-Indonesia border, and the reasons for the fairly abrupt termination in their production from about $3000 \mathrm{BP}$, are significant questions for the future.

\section{Papuan-Austronesian Interaction}

The spectacular spread of Austronesian languages after about $4000 \mathrm{BP}$, and the ensuing settlement of a region extending from Taiwan in the north, to Madagascar in the west, and to Hawaii and Easter Island in the east-and probably further to South and Central America-accounts for scholarly focus on this relatively recent historical "event." The influx of genes, materials, and Austronesian languages to coastal New Guinea and to Island Melanesialong associated, not unproblematically, with the appearance of an iconic, dentate-stamped pottery known as Lapita ware - certainly effected the most profound transformation of these regions since initial settlement (Spriggs 2007). However, the consequences of this development for mainland 
New Guinea beyond the north coast and southeastern PNG were largely indirect. Two important caveats about the probable nature of PapuanAustronesian interaction have been restated recently: the first is that interactions between New Guinea and Wallacea are likely to have extended over a long period of time, almost certainly preceding the $3300 \mathrm{BP}$ date currently accepted for the appearance of Lapita pottery in the local archaeological record, and continuing well after its disappearance, rather than being associated with a single, Lapita-associated period of contact; the second is the gathering evidence for a two-way flow_ - in languages, genes, and materials - between Austronesian- and Papuan-speaking communities.

The first insight, that regional interaction both preceded and followed the local appearance of Austronesian languages, is most clearly expressed in current views on animal and crop introductions (Anderson \& O'Connor 2008; Donohue \& Denham 2010). Pigs, which are present only in small numbers at the earliest Lapita sites, were presumably available in Wallacea and thus potentially in New Guinea before the first Lapita pot was fired. More surprisingly, pig DNA from New Guinea, Island Melanesia, and Polynesia aligns not with the East Asian haplotypes distributed from South China and Taiwan through the Philippines and Micronesia, but instead with a distinct alternative clade introduced from mainland Southeast Asia via the southern chain of Indonesian islands (Larson et al. 2007; Dobney et al. 2008). Dog, one early lineage of which may have been present in Australia and New Guinea slightly before Lapita (though this remains to be confirmed by archaeological finds), was also evidently not part of the early Lapita "package" introduced to Vanuatu and New Caledonia, and emerges as a regular feature of the archaeological record only after 2000 BP (Matisoo-Smith 2007). Three dog haplotypes have been identified for Australia and the Pacific, each linked with a different history of introduction: the A29 haplotype may represent the early introduction of the dingo to Australia and the "singing dog" to New Guinea by 3500 BP, while the D2 and A75 haplotypes are linked to later, separate introductions to Remote Oceania, the first via the north coast of New Guinea and the Bismarck Archipelago and the second more directly from Indonesia to Polynesia (Savolainen et al. 2004).

The second insight addresses the nature of interaction between Austronesian and non-Austronesian communities, and stresses the flow of language elements, genes, and other material in both directions. Pottery, tattooing, polished stone adzes, and domesticated animals may have moved from west to east, but it seems likely now that banana, sugarcane, greater yam, sago, and taro were just some of the domesticates that moved westward from New Guinea and/or Wallacea (Spriggs 2007:106; Donohue \& Denham 2010:235-7). Where earlier linguistic reconstructions proposed the adoption by Papuans of a reconstructed Proto-Oceanic term for Colocasia taro, ${ }^{*} \eta m a o$, together with the crop (Lynch 1981:172), it now appears more probable that early Austronesian-speaking communities in the New Guinea and Bismarck 
Archipelago region added this local variety of a regional domesticate, together with its local term, to their own repertoire (Pawley 2005b:101). However, Barry Craig's (2005) attempt in this volume to propose New Guinea as the source of the design elements on Lapita pottery, based on his analysis of ethnographic material culture, is substantially at odds with recent archaeological evidence for obvious precursors in pre-Lapita pottery to the west of New Guinea (Bellwood 2005b:137-139).

Two aspects of genetic diversity reported in Papuan Pasts, and explored in further detail since, appear to contribute to this sense of more complex processes of exchange between Papuans and Austronesian-speakers. The first is the evidence for admixture between Austronesian-speakers and Indigenous Papuan-speaking communities: while recent advances in genetic technology appear to have reversed some of the claims made earlier about the extent of Indigenous Papuan contribution to the genetic profile of Polynesians, there is some suggestion that admixture may have been more extensive among populations during the Lapita phase of Austronesian expansion, than for later movements that resulted in the settlement of Central and Eastern Polynesia (Addison \& Matisoo-Smith 2010); a model that appears to accord well with the emerging record of animal introductions described above.

The second is the discovery of exceptionally low male or Y-chromosome diversity within Papuan communities of eastern New Guinea, indicating very low rates of male migration, and seemingly reversing the findings for Polynesian and many other Austronesian-speaking communities, which exhibit high male or Y-chromosome diversity but low female or mitochondrial DNA diversity (Harley et al. 2005:736-739; Kayser et al. 2006). More recent reports bring these two findings together, demonstrating that as much as $62 \%$ of Polynesian Y-chromosomes have their origins in New Guinea and its islands, compared to just 33\% that can be traced back to Asia (Kayser 2010:R198). These findings would appear to lend support to the thesis that Early Lapita or Proto-Oceanic society (assuming some homology between the two) was essentially matrilineal in structure and matrilocal in residence pattern, allowing for the in-marriage of men from pre-existing or Indigenous communities (Hage \& Marck 2003; Marck 2008; but see Jordan et al. 2009, who further complicate matters by proposing patrilocality for Proto-Oceanic societies on the basis of cultural phylogenetics).

The recent development of autosomal studies of multiple regions of the nuclear genome has provided a much more complex and potentially accurate understanding of genetic history than available from these earlier studies on either female (mitochondrial) or male (Y-chromosome) haploid data, which have stressed either limited or substantial Austronesian-non-Austronesian admixture, respectively (Friedlander et al. 2008; Cox et al. 2010). While the dynamism of the genetic study of Oceanic populations is exciting, and has the potential to revolutionize the sophistication of our accounts of 
regional history, the very limited conceptions of social process articulated in the framing of genetic problems suggest the central importance of continued exchange or "admixture" with the perspectives of the other historically minded disciplines engaged in the same field.

\section{The Genesis of Modern Communities}

The last three or four centuries have witnessed some of the most dramatic transformations in Papuan history, though this may in part reflect the increased visibility of the details of processes of exchange, adoption, and migration leading into the very recent past. Bryant Allen's analysis of agricultural intensification in the Sepik foothills and the parallel fortunes of the neighboring Abelam and Arapesh groups is the only chapter of Papuan Pasts that directly addresses this period, and the distinctive subtlety of his account of social transformation indicates the potential of such a focus. The limitations of the vocabularies of social change that are employed over broader time-scales and applied to earlier periods are exposed here as both inappropriate and inadequate to the task of explaining social process (Allen 2005:585).

Where detailed and extensive oral historical work has been undertaken, by Polly Wiessner and Akii Tumu (1998) for Enga Province, or by Paul Roscoe (1994) for the Sepik, for example, trajectories for change over the last few centuries become readily apparent. The encyclopedic survey by Wiessner and Tumu of Engan oral traditions traces the movements of early agriculturalists into terrain previously occupied by more mobile communities, the remarkable impact on population growth of the introduction and adoption of sweet potato from about 300 BP-the "Ipomoean Revolution" (Watson 1977; Ballard 2005) - and its consequences for the development of the elaborate regional ceremonial exchange system of the Tee. Changes in subsistence strategies, technology, crops, social structure, patterns of marriage, exchange, and warfare, and regional links through ritual can be mapped and assembled to provide a total social history. It is at this level of detail that we should be able to direct genetic sampling and interrogate regional patterns with some precision: for instance, to explore the basis for reports of gendered variation in gene flow between regions, which suggest female-mediated gene flow (that is, movement primarily of women) between highland regions, in contrast to male-mediated flow between the highlands and lowlands (Kayser et al. 2003).

The Ipomoean Revolution in the New Guinea highlands resulted in significant population increase and movement, with substantial flow from the centers of population in the major valleys to both higher and lower altitudes, and a more vigorously contested lateral flow to highlands regions with lower population densities. Enga-speakers moved in large numbers to lower altitudes below $1300 \mathrm{~m}$ (Dornstreich 1973) and to higher altitudes above 
$2000 \mathrm{~m}$ (Wohlt 1978). Elsewhere, Huli-speakers moved both south to lower valleys and laterally into areas previously occupied by Duna-speakers (Haley 2002); and Western Dani have migrated in very large numbers westwards into valleys formerly dominated by Moni and Damal (Larson 1987). In each of these cases, details of the processes of migration, assimilation, or annihilation, and of the roles in these processes of ritual, marriage, and other forms of exchange, can be reconstructed with some confidence, enabling us to address some of the challenging questions raised in Papuan Pasts, such as the unanticipated profusion of terms for sweet potato in interior New Guinea (Hays 2005:632-633), or the high proportions of resemblant or formally similar vocabulary among the neighboring but unrelated Huli, Duna, and Bogaia languages (Pawley 2005b:78).

\section{CRITICAL SYNTHESES}

This thumbnail sketch of Papuan history is little more than a prologue to the form of synthesis required to set agendas that might harness the complementary strengths of different disciplines. Increasing disciplinary specialization-inevitable, particularly, for population genetics-militates against the easy exchange of results, but makes it all the more important that occasional statements of consensus be attempted (Blench et al. 2008). Such syntheses need not constitute a dumbing down of the subtleties and qualifying riders familiar to the practitioners of individual disciplines (Chalmers et al. 2002:21-22). Rather, a genuine synthesis should aspire to be a complex statement in its own right, something more than the sum of its constituent parts, and with a vocabulary of its own, particularly if the varying units of analysis (such as cultures, practices, languages, haplogroups etc.) are to be made commensurable. Three critical measures of the value of a synthesis include: success in identifying gaps in disciplinary and especially cross-disciplinary coverage; the need for a specific focus or emphasis for the narrative of the synthesis; and the requirement that the synthesis generate propositions or models that lend themselves to being tested individually or collectively by one or more disciplines or subdisciplines.

Gaps in our knowledge of specific areas or periods are readily identified by contributors to Papuan Pasts. In relative terms, there has been more of a focus on the Bismarck Archipelago and the PNG Highlands than on three other areas: the lowland interior of New Guinea (the Bosmun Plateau and the shores of the former Sepik-Ramu Inland Sea, in particular); the more remote islands, including Alor, Pantar, and Timor in the west, and Bougainville and the central Solomon Islands in the east; and the whole of west New Guinea (currently the provinces of Papua and Papua Barat in the Republic of Indonesia). Further afield, the history of Wallacea or eastern 
Indonesia, which should supply an important context for Papuan history, is even less well known in most respects than that of New Guinea.

The only period of the region's history for which there is even adequate coverage is that relating to the production of Lapita pottery, from about 3300-2500 BP, and then only for those areas directly associated with Lapita settlement or trade. Gaps in temporal coverage include periods for which there is little or no evidence, such as the major gap identified for sediment records from New Guinea between 16,000 and 9000 BP (Hope \& Haberle 2005:550), and critical periods in specific areas, such as the duration of the Sepik-Ramu Inland Sea, from before 7500 to about 4000 BP.

Another kind of gap in coverage is that of perspective. Though Papuan Pasts casts a broad net among the relevant disciplines and subdisciplines, some critical strands of evidence are missing, particularly at the juncture between ethnography and history. Anthropologists such as Nicholas Modjeska (1977), James Watson (1977), Maurice Godelier (1986), Daryl Feil (1987), and Pierre Lemonnier (1990) have speculated constructively on social transformations in Papuan societies on the basis of observations on contemporary practices and their distributions; and historians such as Rod Lacey (1975) and ethnoarchaeologists like Polly Wiessner (Wiessner \& Tumu 1998) have addressed oral traditions, read carefully, as valid sources for specific historical events and processes. As noted above, the only chapter of Papuan Pasts directed towards this intersection is that by the geographer, Bryant Allen (2005).

The most important perspective missing in Papuan Pasts is that of the Papuans. Only one of the 45 authors is Papuan: geneticist George Koki, as one of 12 co-authors for an individual chapter. This should give us pause for thought and, at the very least, raise some doubts about the present value of deep history for Papuans. Whatever the reasons for this non-appearance of Papuans as contributors, it surely signals either a broad failure to recruit Papuan researchers in substantial numbers to these disciplines, or a lack of interest among Papuan researchers in the kinds of questions being addressed here - or perhaps both. Anecdotal evidence from my own experience in the region suggests that histories that fail to engage in some measure with the lives and recent historical pasts of living Papuan communities are of lesser interest or significance to those communities. Lapita or Pleistocene sites may evoke some interest among immediate landowners, or even become a source of national pride, but they are unlikely to compete for real attention with sites or events that impinge more obviously on people's lives and concerns. The recent past offers a vital hinge between living Papuan communities and the deeper past, and yet it also provides a critical meeting ground for Papuan and scholarly interests, as well as a lens on the details of processes of social and environmental transformation that might allow us to pose more challenging questions of our evidence for the deeper past. 
Syntheses, as historian Thomas Bender (1986:136) reminds us, require "a center, a point of orientation for the various parts and a focus for narrative energy," and an obvious point of orientation for Papuan histories is the recent past. It is over the period of the past few centuries that we are most likely to be able to appreciate the agency of historical actors and the diversity of strategies at play, together with the range of outcomes, intended and unintended, in any transformational process. As a very general characterization and with some obvious exceptions among the individual chapters, the focus of Papuan Pasts is on origins rather than processes, on the correlation of dates for founder events rather than the exploration or modeling of transformations, and on the deep past, rather than the immediate genesis of the present. Along with a concern for the integrity of the narratives drawing on different disciplinary and subdisciplinary perspectives, evident in the thematic organization of the contributions to Papuan Pasts, this is perhaps a prudent approach for an early stage of inquiry, but reflection on the range of possible alternative structures points to the limitations of the present framework. How differently might individual contributions have been configured had the titles of the thematic sections addressed processes such as "Invention," "Migration," "Transfer," "Adoption," or "Demise"?

The last of the critical measures of the value of a synthesis identified is the requirement of testability, with a preference for hypotheses that pose challenges individually to several disciplines and jointly to the collective. A particularly inspiring model for this form of inquiry is the invention by Nicholas Evans, a linguist, and the late Rhys Jones, an archaeologist, of the device of a hypothetical "quartzite ceremony" as a means of focusing the resources of archaeology, linguistics, and sociocultural anthropology on crucial questions in Pama-Nyungan history in northern Australia, including

... the whole complex of large-scale ritual gathering, socialisation into the religious and social ideology associated with it, technological knowledge passed on through ceremonial induction, and the consequences of social relationships set up in such ceremonies for marriage alliances and ultimate language shift. [Evans \& Jones 1997:412]

By constructing a ceremony that is ethnographically, linguistically, and archaeologically plausible, if undemonstrated, their explicit aim is "to stimulate a new round of hypothesis-testing" (Evans \& Jones 1997:417) by all three anthropological subfields, for each of which visible parameters of change are proposed. Papuan history might benefit from the development of similarly complex scenarios addressing, for example, the archaeologically visible stone mortars and pestles of the Papuan mid-Holocene, which raise questions about the genetic and linguistic evidence for the TNG expansion.

The goal of synthetic inquiry into a regional history is not the "prize" of "a single, coherent, holistic prehistory" (Heggarty 2008:35, editor's preface). 
To be truly productive, historical synthesis has to be more than just the "piecing together [of] findings in a multidisciplinary jigsaw" (Blench et al. 2008:3). It must entail the challenge of finding ways to reconceptualize and generate questions that can attract the attention and test the assumptions of multiple forms of inquiry; a "new holism" pursued "in order to tackle cognate problems genuinely requiring the input of other methodologies" (Parkin 2007:6). What is promoted through this process is a healthy respect for the insights of other disciplines and, reflexively, an awareness of the blind spots and assumptions embedded and unaddressed in one's own disciplinary perspective (and yet so evident in those of other disciplines and even subdisciplines).

No single discipline is "ideally situated" (Donohue \& Denham 2010:249) or enjoys a privileged position in this enterprise, which gathers its strength from the multiplication of lines of inquiry and evidence; and Oceanic scholarship has more to offer in this respect than an exemplary "laboratory" for phylogenetic reconstruction. If, as I have proposed here, reflection on the contribution of Papuan Pasts points to questions of historical process as a broad and largely open field for further research, then the region's vast wealth of ethnographic and ethnohistorical material must also be brought into the fold - as an "Oceanic sacred bundle," perhaps. Ethnography, not just as a quarry for comparative material but also as a locally specific source for analogy and understanding of social process; and oral traditions, because whatever the status of their veracity about the past, they structure human action (and thus the continuing historic record) in the present. Together, and in concert with the other historical disciplines, ethnography and ethnohistory have the potential to substantially enhance our capacity to conceive of and to understand processes of social transformation, in the recent as in the deep past.

\section{ACKNOWLEDGMENTS}

I gratefully acknowledge the tutelage and insightful readings of drafts of this article by Robert Attenborough, Michael Bourke, Nicholas Evans, Jonathan Friedlaender, Jean Kennedy, Andrew Pawley, and Matthew Spriggs, together with comments from an anonymous reader.

\section{REFERENCES CITED}

Addison, David J., and Elizabeth Matisoo-Smith

2010 Rethinking Polynesians [sic] Origins: A West-Polynesia Triple-I Model.

Archaeology in Oceania 45(1):1-12.

Allaby, Robin

2007 Origins of Plant Exploitation in Near Oceania: A Review. In Friedlaender, ed. Pp.181-198. 
Allen, Bryant

2005 The Place of Agricultural Intensification in Sepik Foothills Prehistory.

In Pawley, Attenborough, Golson, and Hide, eds. Pp. 585-623.

Allen, Jim, and James F. O'Connell

2008 Getting from Sunda to Sahul. In Islands of Inquiry: Colonisation, Seafaring and the Archaeology of Maritime Landscapes, Geoffrey Clark, Foss Leach, and Sue O'Connor, eds. Pp. 32-46. Canberra: ANU E Press.

Anderson, Atholl, and Sue O'Connor

2008 Indo-Pacific Migration and Colonization: Introduction. Asian Perspectives 47(1):2-11.

Ballard, Chris

2005 Still Good to Think with: The Sweet Potato in Oceania. In The Sweet Potato in Oceania: A Reappraisal, Chris Ballard, Paula Brown, R. Michael Bourke, and Tracy Harwood, eds. Pp.1-13. Sydney and Pittsburgh: University of Sydney and University of Pittsburgh.

2008 "Oceanic Negroes": Early British Anthropology of Papuans, 1820-1869.

In Foreign Bodies: Oceania and the Science of Race, 1750-1940, Bronwen

Douglas and Chris Ballard, eds. Pp. 157-201. Canberra: ANU E Press.

Bellwood, Peter

2005a New Guinea and Its Place in World Prehistory. The Review of

Archaeology 26(2):10-17.

2005b First Farmers: The Origins of Agricultural Societies. Oxford: Blackwell Publishing.

Bellwood, Peter, James J. Fox, and Darrell Tryon, eds.

1995 The Austronesians: Historical and Comparative Perspectives. Canberra:

Department of Anthropology, Australian National University.

Bellwood, Peter, and Colin Renfrew, eds.

2002 Examining the Farming/Language Dispersal Hypothesis. Cambridge:

McDonald Institute for Archaeological Research.

Bender, Thomas

1986 Wholes or Parts: The Need for Synthesis in American History. The Journal

of American History 73(1):120-136.

Blench, Roger, Malcolm Ross, and Alicia Sanchez-Mazas

2008 Methodological Issues: Linking Genetic, Linguistic and Archaeological

Evidence. In Past Human Migrations in East Asia: Matching Archaeology,

Linguistics and Genetics, Alicia Sanches-Mazas, Roger Blench, Malcolm D. Ross, et al., eds. Pp. 3-19. London: Routledge.

Chalmers, Iain, Larry V. Hedges, and Harris Cooper

2002 A Brief History of Research Synthesis. Evaluation and the Health

Professions 25(1):12-37.

Chappell, John

2005 Geographic Changes of Coastal Lowlands in the Papuan Past. In Pawley,

Attenborough, Golson, and Hide, eds. Pp. 525-539.

Cox, Murray P., Tatiana M. Karafet, J. Stephen, Lansing, Herawati Sudoyo, and Michael F. Hammer

2010 Autosomal and X-Linked Single Nucleotide Polymorphisms Reveal

a Steep Asian-Melanesian Ancestry Cline in Eastern Indonesia and a 
Sex Bias in Admixture Rates. Proceedings of the Royal Society B 277:1589-1596.

Craig, Barry

2005 What Can Material Culture Studies Tell Us about the Past in New Guinea? In Pawley, Attenborough, Golson, and Hide, eds. Pp. 493-513.

Denham, Tim

2007a Exploiting Diversity: Plant Exploitation and Occupation in the Interior of

New Guinea during the Pleistocene. Archaeology in Oceania 42(2):41-48.

2007b Early to Mid-Holocene Plant Exploitation in New Guinea: Towards a

Contingent Interpretation of Agriculture. In Rethinking Agriculture:

Archaeological and Ethnoarchaeological Perspectives, Tim Denham, José

Iriarte, and Luc Vrydaghs, eds. Pp. 78-108. Walnut Creek, CA: Left Coast Press.

Denham, Tim, and Mark Donohue

2009 Pre-Austronesian Dispersal of Banana Cultivars West from New Guinea:

Linguistic Relics from Eastern Indonesia. Archaeology in Oceania 44(1):18-28.

Denham, Tim, Richard Fullagar, and Lesley Head

2008 Plant Exploitation on Sahul: From Colonisation to the Emergence of Regional Specialisation during the Holocene, Quaternary International 30:1-12.

Dobney, Keith, Thomas Cucchi, and Greger Larson

2008 The Pigs of Island Southeast Asia and the Pacific: New Evidence for Taxonomic Status and Human-Mediated Dispersal. Asian Perspectives 47(1):59-74.

Donohue, Mark, and Tim Denham

2010 Farming and Language in Island Southeast Asia: Reframing Austronesian History. Current Anthropology 51(2):223-256.

Dornstreich, Mark David

1973 An Ecological Study of Gadio Enga (New Guinea) Subsistence. Ph.D. dissertation, Columbia University. Ann Arbor: University Microfilms International.

Easteal, Simon, Belinda Whittle, Andrea Mettenmeyer, Robert Attenborough, Kuldeep Bhatia, and Michael P. Alpers

2005 Mitochondrial Genome Diversity among Papuan-speaking People of Papua New Guinea. In Pawley, Attenborough, Golson, and Hide, eds. Pp. 717-728.

Evans, Nicholas, and Rhys Jones

1997 The Cradle of the Pama-Nyungans: Archaeological and Linguistic Speculations. In Archaeology and Linguistics: Aboriginal Australia in Global Perspective, Patrick McConvell and Nicholas Evans, eds. Pp. 385-417. Oxford: Oxford University Press.

Fairbairn, Andrew S., Geoffrey S. Hope, and Glenn R. Summerhayes 2006 Pleistocene Occupation of New Guinea's Highland and Subalpine Environments. World Archaeology 38(3):371-386.

Feil, D. K.

1987 The Evolution of Highland Papua New Guinea Societies. Cambridge:

Cambridge University Press. 
Friedlaender, Jonathan S.

2007a Conclusion. In Friedlaender, ed. Pp. 231-237.

Friedlaender, Jonathan S., ed.

2007b Genes, Language, and Culture History in the Southwest Pacific. Oxford:

Oxford University Press.

Friedlaender, Jonathan S., Françoise R. Friedlaender, Floyd A. Reed, Kenneth K.

Kidd, Judith R. Kidd, Geoffrey K. Chambers, Rodney A. Lea, Jun-Hun Loo, George

Koki, Jason A. Hodgson, D. Andrew Merriwether, and James L. Weber

2008 The Genetic Structure of Pacific Islanders. PLoS Genetics 4(1):173-190.

Friedlaender, Jonathan, Fred Gentz, Françoise R. Friedlaender, Frederika Kaestle,

Theodore Schurr, George Koki, Moses Schanfield, John McDonough, Lydia Smith,

Sal Cerchio, Charles Mgone, and D. Andrew Merriwether

2005 Mitochondrial Genetic Diversity and its Determinants in Island Melanesia.

In Pawley, Attenborough, Golson, and Hide, eds. Pp. 693-716.

Gelpke, J. H. F. Sollewijn

1993 On the Origin of the Name Papua. Bijdragen tot de Taal-, Land- en

Volkenkunde 149:318-332.

Godelier, Maurice

1986 The Making of Great Men: Male Domination and Power among the

New Guinea Baruya. Cambridge and Paris: Cambridge University Press and

Editions de la Maison des Sciences de l'Homme.

Golson, Jack

2005 The Middle Reaches of New Guinea History. In Pawley, Attenborough,

Golson, and Hide, eds. Pp. 451-491.

Green, Roger

1991 Near and Remote Oceania: Disestablishing "Melanesia" in Culture History.

In Man and a Half: Essays in Pacific Anthropology and Ethnobiology in Honour of Ralph Bulmer, Andrew Pawley, ed. Pp. 491-502. Auckland: Polynesian

Society.

Gruhn, Ruth

2006 Reconstructing Prehistoric Population Movements: Seeking Congruence

in Genetics. Linguistics, and Archaeology, Reviews in Anthropology

35(4):345-372.

Hage, Per, and Jeff Marck

2003 Matrilineality and the Melanesian Origin of Polynesian Y Chromosomes.

Current Anthropology 44:S121-S127.

Haley, Nicole Clair

2002 Ipakana Yakaiya: Mapping Landscapes, Mapping Lives: Contemporary

Land Politics among the Duna. Ph.D. dissertation, The Australian National

University.

Harkin, Michael E.

2010 Uncommon Ground: Holism and the Future of Anthropology. Reviews

in Anthropology 39(1):25-45.

Harley, Nerida, Robert Attenborough, Michael P. Alpers, Charles Mgone, Kuldeep Bhatia, and Simon Easteal

2005 The Importance of Social Structure for Patterns of Human Genetic

Diversity: Y-Chromosome and Mitochondrial Genome Variation in 
Papuan-Speaking People of Mainland New Guinea. In Pawley,

Attenborough, Golson, and Hide, eds. Pp. 729-755.

Hays, Terence E.

2005 Vernacular Names for Tubers in Irian Jaya: Implications for Agricultural

Prehistory. In Pawley, Attenborough, Golson, and Hide, eds. Pp. 625-670.

Heggarty, Paul

2008 Linguistics for Archaeologists: A Case-Study in the Andes. Cambridge

Archaeological Journal 18(1):35-56.

Hill, Jonathan D., and Fernando Santos-Granero, eds.

2002 Comparative Arawakan Histories: Rethinking Language Family and Culture Area in Amazonia. Urbana: University of Illinois Press.

Hope, Geoffrey S., and Simon G. Haberle

2005 The History of the Human Landscapes of New Guinea. In Pawley, Attenborough, Golson, and Hide, eds. Pp. 541-554.

Hudjashov, Georgi, Toomas Kivisild, Peter A. Underhill, Phillip Endicott, Juan J. Sanchez, Alice A. Lin, Peidong Shen, Peter Oefner, Colin Renfrew, Richard Villems, and Peter Forster

2007 Revealing the Prehistoric Settlement of Australia by Y Chromosome and mtDNA Analysis, Proceedings of the National Academy of Sciences 104(21):8726-8730.

Jordan, Fiona M., Russell D. Gray, Simon J. Greenhill, and Ruth Mace

2009 Matrilocal Residence Is Ancestral in Austronesian Societies, Proceedings of the Royal Society B 276:1957-1964.

Kayser, Manfred

2010 The Human Genetic History of Oceania: Near and Remote Views of Dispersal. Current Biology 20:R194-R201.

Kayser, Manfred, Silke Brauer, Gunter Weiss, Wulf Schiefenhövel, Peter Underhill Peidong Shen, Peter Oefner, Mila Tommaseo-Ponzetta, and Mark Stoneking

2003 Reduced Y-Chromosome, but not Mitochondrial DNA, Diversity in Human Populations from West New Guinea. American Journal of Human Genetics 72:281-302.

Kayser, Manfred, Silke Brauer, Richard Cordaux, Amanda Casto, Oscar Lao,

Lev A. Zhivotovsky, Claire Moyse-Faurie, Robb B. Rutledge, Wulf Schiefenhövel, David Gil, Alice A. Lin, Peter A. Underhill, Peter J. Oefner, Ronald J. Trent, and Mark Stoneking

2006 Melanesian and Asian Origins of Polynesians: mtDNA and

Y Chromosome Gradients across the Pacific. Molecular Biology and Evolution 23(11):2234-2244.

Kennedy, Jean

2006 Review of Papuan Pasts. Archaeology in Oceania 41(3):130-133.

2009 Bananas: Towards a Revised Prehistory. In From Foragers to Farmers:

Papers in Honour of Gordon C. Hillman, Andrew S. Fairbairn, and Ehud Weiss, eds. Pp. 190-204. Oxford: Oxbow.

Kennedy, Jean, and William Clarke

2004 Cultivated Landscapes of the Southwest Pacific. RMAP Working Paper 50.

Canberra: Resource Management in Asia Pacific Program, The Australian

National University. 
Kirch, Patrick Vinton, and Roger C. Green

2001 Hawaiki, Ancestral Polynesia: An Essay in Historical Anthropology.

Cambridge: Cambridge University Press.

Kirch, Patrick Vinton, and Marshall Sahlins

1992 Anahulu: The Anthropology of History in the Kingdom of Hawaii.

Chicago: University of Chicago Press.

Lacey, Roderic John

1975 Oral Traditions as History: An Exploration of Oral Sources among the

Enga of the New Guinea Highlands. Ph.D. dissertation, University of Wisconsin. Larson, Gordon F.

1987 The Structure and Demography of Cycles of Warfare among the

Ilaga Dani of Irian Jaya. Ph.D. dissertation, University of Michigan.

Larson, Greger, Thomas Cucchi, and Masakatsu Fujita, Elizabeth Matissoo-Smith, Judith Robins, Atholl Anderson, Barry Rolett, Mathew Spriggs, Gaynor Dolman,

Tae-Hun Kim, Nguyen Thi Dieu Thuy, Ettore Randi, Moira Doherty, Rokus Awe Due, Robert Bollt, Tony Djubiantono, Bion Griffin, Michiko Intoh, Emile

Keane, Patrick Kirch, Kuang-Ti Li, Michael Morwood, Lolita M. Pedriña, Philip

J. Piper, Ryan J. Rabett, Peter Shooter, Gert Van den Bergh, Eric West, Stephen

Wickler, Jing Yuan, Alan Cooper, and Keith Dobney

2007 Phylogeny and Ancient DNA of Sus Provides Insights into Neolithic

Expansion in Island Southeast Asia and Oceania. Proceedings of the National

Academy of Sciences 104(12):4834-4839.

Lemonnier, Pierre

1990 Guerres et Festins. Paix, échanges et compétition dans les Highlands de

Nouvelle-Guinée. Paris: Editions de la Maison des Sciences de l'Homme.

Leyden, J.

1811 On the Languages and Literature of the Indo-Chinese Nations. Asiatic

Researches 10:158-289.

Lynch, John

1981 Austronesian "Loanwords" (?) in Trans-New Guinea Phylum Vocabulary.

In Papers in New Guinea Linguistics, 21:165-180. Series A-61. Canberra: Pacific Linguistics.

McConvell, Patrick, and Nicholas Evans, eds.

1997 Archaeology and Linguistics: Aboriginal Australia in Global Perspective.

Oxford: Oxford University Press.

Marck, Jeff

2008 Proto Oceanic Society Was Matrilineal. Journal of the Polynesian Society 117(4):345-382.

Matisoo-Smith, Elizabeth

2007 Animal Translocations, Genetic Variation, and the Human Settlement

of the Pacific. In Friedlaender, ed. Pp. 157-170.

Modjeska, C. J. N.

1977 Production among the Duna: Aspects of Horticultural Intensification in

Central New Guinea. Ph.D. dissertation, Australian National University.

Mona, Stefano, Katharina E. Grunz, Brigitte Pakendorf, Loredana Castri, Herawati

Sudoyo, Sangkot Marzuki, Robert H. Barnes, Jörge Schmidtke, Mark Stoneking, and Manfred Kayser 
2009 Genetic Admixture History of Eastern Indonesia as Revealed by

Y-Chromosome and Mitochondrial DNA Analysis. Molecular Biology and

Evolution 26(8):1865-1877.

Mona, Stefano, Mila Tommaseo-Ponzetta, Silke Brauer, Herawati Sudoyo, Sangkot

Marzuki, and Manfred Kayser

2007 Patterns of Y-Chromosome Diversity Intersect with the Trans-New Guinea Hypothesis. Molecular Biology and Evolution 24(1):2546-2555.

Nichols, Johanna

1997 Sprung from Two Common Sources: Sahul as a Linguistic Area. In

Archaeology and Linguistics: Aboriginal Australia in Global Perspective, Patrick McConvell and Nicholas Evans, eds. Pp. 135-168. Oxford: Oxford University Press.

O'Connor, Sue

2007 New Evidence from East Timor Contributes to Our Understanding of Earliest Modern Human Colonisation East of the Sunda Shelf. Antiquity 81:523-535.

O'Connor, Sue, and John Chappell

2003 Colonisation and Coastal Subsistence in Australia and Papua New Guinea: Different Timing, Different Modes? In Pacific Archaeology: Assessments and Prospects, Christophe Sand, ed. Pp. 17-32. Noumea: Département d'Archéologie, Service des Musées et du Patrimoine.

Parkin, David

2007 Emergence and Convergence. In Holistic Anthropology: Emergence and Convergence, David Parkin and Stanley Ulijaszek, eds. Pp. 1-20. New York: Berghahn Books.

Parkin, David, and Stanley Ulijaszek eds.

2007 Holistic Anthropology: Emergence and Convergence. New York:

Berghahn Books.

Pawley, Andrew

2005a Preface. In Pawley, Attenborough, Golson, and Hide, eds.

Pp. xi-xvii.

2005b The Chequered Career of the Trans New Guinea Hypothesis: Recent

Research and Its Implications. In Pawley, Attenborough, Golson, and Hide, eds. Pp. 67-107.

Pawley, Andrew, and Roger Green

1973 Dating the Dispersal of the Oceanic Languages. Oceanic Linguistics 12:1-67.

Pawley, Andrew, Robert Attenborough, Jack Golson, and Robin Hide, eds.

2005 Papuan Pasts: Cultural, Linguistic and Biological Histories of

Papuan-Speaking Peoples. Canberra: Pacific Linguistics, Research School of

Pacific and Asian Studies, The Australian National University.

Ray, Sidney Herbert

1926 A Comparative Study of the Melanesian Island Languages. Cambridge:

Cambridge University Press.

Reesink, Ger, Ruth Singer, and Michael Dunn

2009 Explaining the Linguistic Diversity of Sahul Using Population Models.

PLoS Biology 7(11):1-9. 
Roscoe, Paul

1994 Who Are the Ndu? Ecology, Migration, and Linguistic and Cultural Change in the Sepik Basin. In Migration and Transformations: Regional Perspectives on New Guinea, Andrew J. Strathern and Gabriele Stürzenhofecker, eds. Pp. 49-84. Pittsburgh: University of Pittsburgh Press.

2005 Foraging, Ethnographic Analogy, and Papuan Pasts: Contemporary Models for the Sepik-Ramu Past. In Pawley, Attenborough, Golson, and Hide, eds. Pp. 555-584.

Ross, Malcolm

2006 Clues to the Linguistic Situation in Near Oceania Before Agriculture.

Paper presented at the Symposium "Historical Linguistics and

Hunter-Gatherer Populations in Global Perspective," MPI-EVA Leipzig, 10-12 August.

Sagart, Laurent, Roger Blench, and Alicia Sanchez-Mazas, eds.

2005 The Peopling of East Asia: Putting together Archaeology, Linguistics and

Genetics. New York: RoutledgeCurzon.

Sanches-Mazas, Alicia, Roger Blench, and Malcolm D. Ross et al. eds.

2008 Past Human Migrations in East Asia: Matching Archaeology, Linguistics and Genetics. London: Routledge.

Savolainen, Peter, Thomas Leitner, Alan N. Wilton, Elizabeth Matisoo-Smith, and Joakim Lundeberg

2004 A Detailed Picture of the Origin of the Australian Dingo, Obtained from the Study of Mitochondrial DNA. Proceedings of the National Academy of Science 101(33):12387-12390.

Segal, Daniel A., and Sylvia J. Yanagisako eds.

2005 Unwrapping the Sacred Bundle: Reflections on the Disciplining of

Anthropology. Durham: Duke University Press.

Smith, David G.

2010 The Consequences of Early Food Production: Three Recent Contributions. Reviews in Anthropology 39(2):91-107.

Specht, Jim

2005 Revisiting the Bismarcks: Some Alternative Views. In Pawley,

Attenborough, Golson, and Hide, eds. Pp. 235-288.

Spriggs, Matthew

2007 The Neolithic and Austronesian Expansion within Island Southeast Asia and into the Pacific. In From Southeast Asia to the Pacific: Archaeological Perspectives on the Austronesian Expansion and the Lapita Cultural Complex, S. Chiu and C. Sand, eds. Pp. 104-140. Taipei: Academica Sinica.

Summerhayes, Glenn

2007 Island Melanesian Pasts: A View from Archeology. In Friedlaender, ed.

Pp. 10-35.

Swadling, Pamela, and Robin Hide

2005 Changing Landscape and Social Interaction: Looking at Agricultural History from a Sepik-Ramu Perspective. In Pawley, Attenborough, Golson, and Hide, eds. Pp. 289-327. 
Swadling, Pamela, Polly Wiessner, and Akii Tumu

2008 Prehistoric Stone Artefacts from Enga and the Implication of Links between the Highlands, Lowlands and Islands for Early Agriculture in Papua New Guinea. Journal de la Société des Océanistes 126-127(1/2): 271-292.

Terrill, Angela

2007 Review of Papuan Pasts. Oceanic Linguistics 46(1):313-321.

Thomas, Nicholas

1989 The Force of Ethnology: Origins and Significance of the Melanesia/ Polynesia Division. Current Anthropology 30(1):27-41.

Watson, James B.

1977 Pigs, Fodder and the Jones Effect in Postipomoean New Guinea. Ethnology 16(1):57-70.

Wiessner, Polly, and Akii Tumu

1998 Historical Vines: Enga Networks of Exchange, Ritual and Warfare in

Papua New Guinea. Washington: Smithsonian Institution Press.

Wohlt, Paul B.

1978 Ecology, Agriculture and Social Organization: The Dynamics of Group

Composition in the Highlands of Papua New Guinea. Ph.D. dissertation, University of Minnesota.

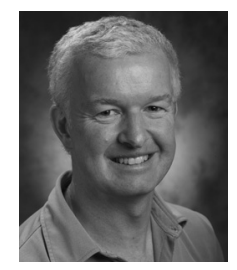

CHRIS BALLARD is Fellow in Pacific History at the Australian National University in Canberra. He has conducted long-term field research as an archaeologist, historian, and sociocultural anthropologist in Papua New Guinea, Vanuatu, and eastern Indonesia. Current research interests include a project on "European Naturalists and the Constitution of Human Difference in Oceania, " and a role as principal researcher for the successful nomination for inscription of the "Chief Roi Mata's Domain" World Heritage site in Vanuatu. Recent publications include the co-edited volumes Foreign Bodies: Oceania and the Science of Race, 1750-1940 (2008) and The Sweet Potato in Oceania (2005). 